situation in China, "you get the feeling, as we did back then, that we are about to see a major expansion in the epidemic."

Limited international funding is al ready given directly to Chinese projects. For example, UNAIDS has provided money for research into an AIDS vaccine by the deputy director of NCAIDS, Yiming Shao. China is also completing negotiations with the World Bank for a loan that will include roughly $\$ 25$ million for treating STDs and for heal th edu-

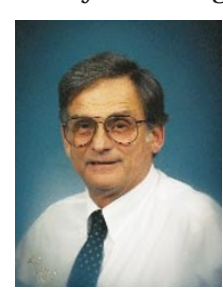

Arthur Ammann join NCAIDS to set up clinical trials in six provinces and Beijing, identifying HIVpositive women of child-bearing age, following them through pregnancy, and treating them with antiviral drugs and traditional medicines to prevent vertical transmission. Cao estimates she will need $\$ 150,000 /$ year over three years to run this trial. She has received $\$ 25,000$ from NCAIDS and is expecting $\$ 15,000$ from the Lloyd Foundation in Los Angeles. The pharmaceutical companies cation to prevent HIV transmission. But Glaxo Wellcome and Merck \& Co. will Ammann wants to fund programs that provide triple drug therapy free of charge will work quickly to prevent the spread of for one year. Ammann's new Californiathe virus. He is focusing efforts on block- based organization, Global Strategies for ing perinatal transmission of HIV.

One example of the type of work that needs to be done is a project being planned by Cao, an American citizen born in China who has worked at the Aaron Diamond AIDS Research Center in New York for the past 12 years. She agreed to
HIV Prevention, has provided some assistance to pay for laboratory technicians for one year, but Cao still lacks funds for reagents to test patient blood samples for viral load.

Amman told Nature Medicine that his efforts were restricted within PAF and
AmFAR, which do not have an international focus. His new organization is independent, and as such heis not beholden to a board of directors; thus, hesays, hecan do things that other organizations cannot. For example, UNAIDS, the World Bank and National Institutes of Health are all funding some HIV research in China, yet he says it took his efforts, connections and moneyproviding travel grants for Chinese scientists-to orchestrate the congressional briefing. He has the time, skills and some money to commit to these projects.

Even before he gets his reply from Congress, Ammann will have moved on to seek support from other groups. Along with the participants from China, he will be meeting Jerry Keusch, director of the Fogarty International Center at the $\mathrm{NIH}$, and Anthony Fauci, director of NIH's National Institute of Allergy and Infectious Diseases to ask whether these organizations can help in China's battle against HIV.

Myrna E. Watanabe, Connecticut

\section{Japan reorganizes national biomedical research groups}

Faced with the reality that it is lagging be hind the United States and some European countries in capitalizing on the fields of biotechnology and genomics research, Japan is taking steps to bolster its output in these areas. Last month, the bioscience panel of the Education Ministry's Science Council announced that it will re vitalize Japan's genome research programs. In addition, the country's five biotechnology-related government agencies are drawing-up guidelines to promote the country's biotechnology industry. They have until the next budget round in June to establish detailed plans.

The initiatives demonstrate the government's decision to promote more commercially oriented research over academic research - a move that some Japanese researchers are finding hard to adjust to.

The government estimates the market potential for biotechnology-related products and services at Yen 25 trillion (US $\$ 210$ billion) in 2010, and ambitiously called for the creation of 1,000 start-up companies with government support under a new legislation passed last year. But Shigekazu Nagata, a professor in the department of Genetics at Osaka University, believes that the government should stick to its policy "of enhancing basic research and theinternational profile of Japanese biomedical research." Nagata says he is "skeptical" about the government's proposal to act, in effect, as a venture-capital source for new biotech companies: "the government should limit itself to creating an optimal environment in which venture-companies and academia-industry relations can develop."

Until now, most of Japan's genome research has been small-scale and concentrated in universities. However, an interim report on genomics research used by the Education Ministry to make a case for reform, notes that "the university research system is badly adapted to the promotion of large-scale projects." Thus, government funding is increasingly being transferred towards large facilities. For example, the RIKEN Genome Frontier Research Center, to be built in Yokohama by 2001, will focus on functional genomics and protein analysis. And the Ministry for International Trade and Industry (MITI) islikely to reinforcefinancial support for Helix Corporation, a functional genomics venture involving several pharmaceutical companies.

Kazuo Katao, director of MITI's Biochemical Industry Division, confirms the shift. "Only a few years ago it was unknown for MITI to finance research into topics like human cDNA," says Katao; but last year MITI received Yen5 billion in additional funding for new programs in industry-based research on full-length human CDNA and bioinformatics.

While many geneticists agreethat largescale programs are necessary, not all are convinced that the right approach is being taken. Yusuke Nakamura, director of the Human Genome Center at Tokyo University's Institute of Medical Science, says he is "strongly dissatisfied" with the way research policy matters are handled in Japan. "Each ministry decides how to use funding without any national strategy for human genetics," he complains. According to Nakamura, decisions about new large-scale genome research projects, such as the RIKEN Genome Frontier Center, have been made behind closed doors. "We were informed only after the fact," he says.

In other news, the government has specified that most national research institutes will be converted into administrative agencies similar to RIKEN. Although universities werenot mentioned in the plan, and the Education Minister, Akito Arima, stressed that a decision on their status will not be made before 2004, many scientists agree that this is simply a tactical maneuver to accustom universities to the changes that lie ahead.

Robert TrIendi, Tokyo 